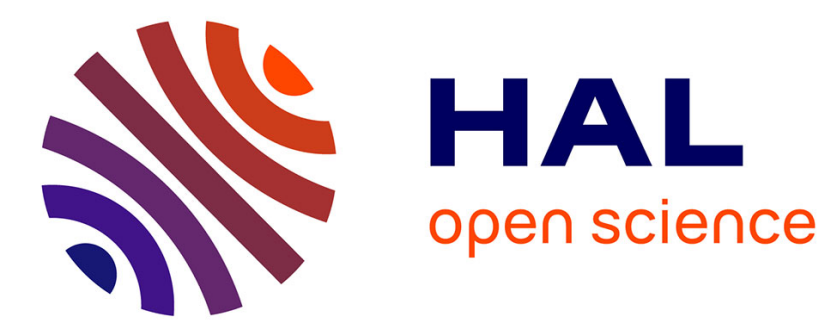

\title{
PALEOMAGNETIC EVIDENCE-FOR ROTATION IN OPPOSITE SENSES OF ADJACENT BLOCKS IN NORTHEASTERN AEGEA AND WESTERN
}

\author{
C. Kissel, C. Laj, A. Şengör, A. Poisson
}

\section{- To cite this version:}

C. Kissel, C. Laj, A. Şengör, A. Poisson. PAlEOMAGNETIC EVIDENCE-FOR ROTATION IN OPPOSITE SENSES OF ADJACENT BLOCKS IN NORTHEASTERN AEGEA AND WESTERN.

Geophysical Research Letters, 1987, 14 (9), pp.907-910. 10.1029/GL014i009p00907 . hal-03548818

\section{HAL Id: hal-03548818 \\ https://hal.science/hal-03548818}

Submitted on 31 Jan 2022

HAL is a multi-disciplinary open access archive for the deposit and dissemination of scientific research documents, whether they are published or not. The documents may come from teaching and research institutions in France or abroad, or from public or private research centers.
L'archive ouverte pluridisciplinaire HAL, est destinée au dépôt et à la diffusion de documents scientifiques de niveau recherche, publiés ou non, émanant des établissements d'enseignement et de recherche français ou étrangers, des laboratoires publics ou privés. 


\title{
PALEOMAGNETIC EVIDENCE -FOR ROTATION IN OPPOSITE SENSES OF ADJACENT
} BLOCKS IN NORTHEASTERN AEGEA AND WESTERN ANATOLIA.

\author{
C. Kissel, ${ }^{1}$ C. Laj, ${ }^{1}$ A.M.C. Şengör, ${ }^{2}$ and A. Poisson, ${ }^{3}$
}

Abstract. Paleomagnetic data from western Anatolia and from the island of Lesbos demonstrate significant counterclockwise, clockwise or null rotations of coherent blocks which occurred during the neotectonic period. These results suggest that the brittle carapace of the lithosphere may not everywhere follow the motion of the ductile lower part but that its movement arises from adjustment to the extensional tectonic regime.

\section{Introduction}

As a result of the intracontinental convergence in Eastern Turkey, most of Turkey moved westward along the North and East Anatolian strike-slip faults. Since at least late Miocene, this motion is accompanied by large scale $\mathrm{N}-\mathrm{S}$ extension in the Aegean and in Western Turkey with complementary $\mathrm{E}-\mathrm{W}$ shortening (Tapponnier, 1977; Dewey and Sengör, 1979; Mercier et al., 1979; Le Pichon and Angelier, 1981; Angelier et al., 1981).

In this paper we report paleomagnetic data from northeastern Aegea showing that significant rotations of adjacent coherent blocks about vertical axes and in opposite senses have occurred in this region since at most $20 \mathrm{~m} . \mathrm{y}$. Although the data are still incomplete, the complicated rotational pattern in this area is easier to describe in terms of local rotations than in the framework of the general westward movement of the "Anatolian Plate" resulting from the Eurasia-Arabia collision (Tapponnier, 1977; Dewey and Sengör, 1979).

\section{Geological Setting and Sampling}

The studied area and the location of the sampling sites are shown in Figure 1.

The most striking structural and morphological features of this region are the $\mathrm{E}-\mathrm{W}$ and NNE trending grabens (McKenzie, 1978; Dewey and Sengör, 1979). Focal mechanism solutions obtained from the Alasehir and Gediz grabens, have shown that motion takes place on faults of listric geometry (Eyidogan and Jackson, 1985). The NNE faults are probably partially inherited from Neo-Tethyan-structures while the $\mathrm{E}-\mathrm{W}$ fault system corresponds to a neotectonic structural direction. The complex pattern of faulting includes numerous other neotectonic faults of various orientations and displacements (Kaya,1981), most of which are truncated by younger faults of different orientations. Slickensides indicating strike-slip movements in opposite senses and in different directions are also frequently observed in the field.

Widespread calc-alkaline volcanic products erupted during the first Aegean phase of

${ }^{1}$ Centre des Faibles Radioactivités, Laboratoire CEA/CNRS, Gif/Yvette, France.

2ITU Maden Fakültesi, Jeoloji Bölümü, Istanbul, Turkey.

${ }^{3}$ Laboratoire de Géologie Historique, Université Paris XI, France.

Copyright 1987 by the American Geophysical Union.

Paper number 717176 .

0094-8276/87/007L-7176\$03.00
Oligo-Miocene age, which ended about $13 \mathrm{~m} . \mathrm{y}$. ago, and small volumes of lava with variable petrogenetic character are present in Central Aegea and Western Anatolia (Borsi et al., 1972; Fytikas et al., 1984).

In Lesbos, 25 sites were sampled mainly in lava flows of dacitic composition, ignimbrites and dykes dated between $15-20 \mathrm{Ma}$ by $\mathrm{K} / \mathrm{Ar}$ (Borsi et al., 1972) and two in blue-grey lacustrine marls of probable Pliocene age.

In Western Anatolia 28 sites were sampled in calcalkaline lava flows dated between 18 and 21 $\mathrm{Ma}$ and in alkali-basalts dated at about 10-11 Ma (Borsi et al., 1972; Fytikas et al., 1984). A few sedimentary and volcano-sedimentary formations were also sampled (12 sites).

For the volcanic formations, interbedded sediments have yielded in some cases precise bedding corrections. In others a local structural study gave a reasonable estimate. In the Canakkale region the basement is unconformably overlain by Neogene lacustrine formations tilting northward with a shallow dip of about $15^{\circ}$. We have assumed that this general bedding attitude affects the sampled sites, which are devoid of local bedding criteria. Finally, when no precise correction for tilting was possible we had to rely on a subjective choice of "almost horizontal" lava flows based on the morphology of the flow itself.

At each site, the cores were obtained over at least a few tens of meters and were oriented with both magnetic and sun compass. A total of 800 cores from 67 sites were sampled and studied.

\section{Laboratory Methods}

Measurements have been done using a spinner or a cryogenic magnetometer. IRM acquisition in fields up to $1.6 \mathrm{~T}$, followed by $A C$ and/or thermal demagnetization. of the SIRM, shows that magnetite is the main magnetic carrier, sometimes associated with a small amount of magnetic minerals of higher coercivity.

Both thermal and $A F$ stepwise demagnetization were used. However the thermal treatment was generally preferred because it yielded overall more consistent results. Each single sample has been stepwise demağnetized with $12-15$ steps between room temperature and at least $580^{\circ} \mathrm{C}$. Both for volcanic and sedimentary samples, no significant changes in susceptibility values occur up to the highest temperatures showing that the magnetic minerals have not changed during the thermal treatment. Typical demagnetization diagrams are shown on Figure 2.

Results

The laboratory measurements have shown that some of the sampled lithologies are not suitable for a paleomagnetic study. In particular different sites in the ignimbrites and the dykes in Lesbos sometimes gave conflicting results and usually an unreasonable within-site scatter, although single samples are characterized by perfectly rectilinear demagnetization diagrams. This phenomenon is not fully understood, but we have considered reliable only the sites for which the Fisherian precision coefficient $K$ was greater than 15. Ten sites in Lesbos and 15 sites in Western Anatolia, were rejected on this basis, leaving 42 trustworthy sites. 


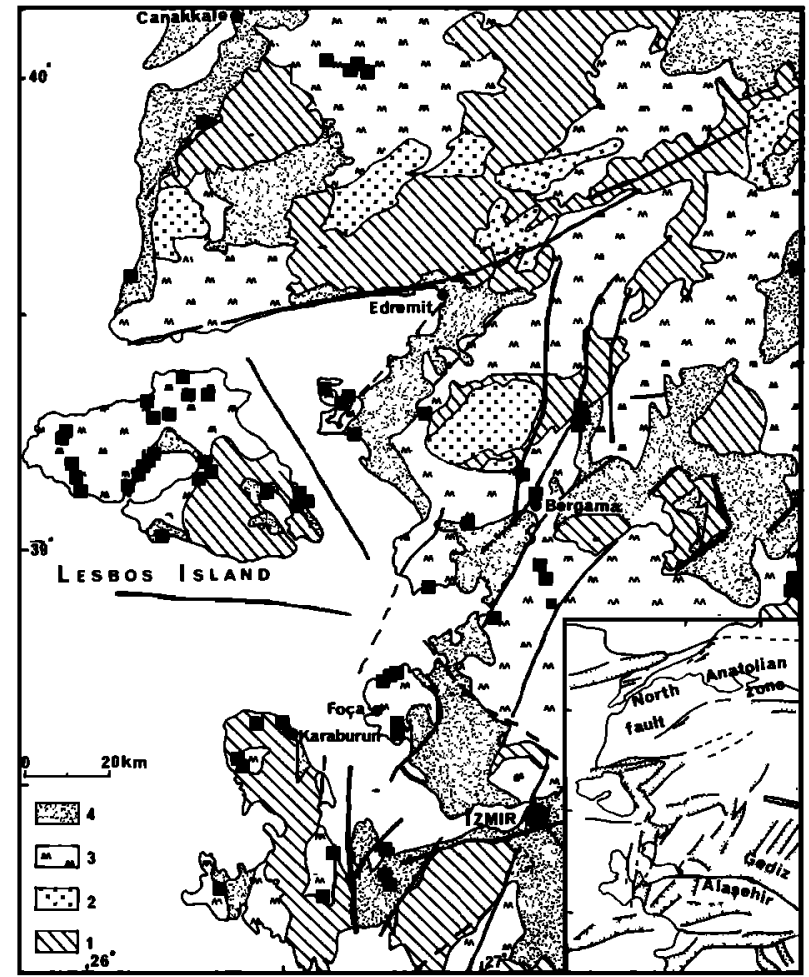

Fig. 1. Schematic map of Northeastern Aegea showing (A) the most proeminent structural. characteristics (the $E-W$ and NNE trending grabens) and (B) the location of the sampled paleomagnetic sites. Symbols: 1: Neogene continental basins; 2: Neogene volcanic and volcano-sedimentary formations; 3: Neogene plutonic formations; 4: Paleozoic basement.

All the reliable results are reported in Table $I$ and on Figure 3, together with 3 sites (Cesme 1,2 , 3) from the Karaburun peninsula reported by Lauer (1981). In each region the normal and reversed directions are antipodal, indicating a good magnetic stability and a satisfactory cleaning.

After bedding correction the inclination values from the different regions are quite consistent, with mean values around $50^{\circ}$, except for the one calculated from the 3 sites south of Bergama which is shallower.

The mean declinations from the different

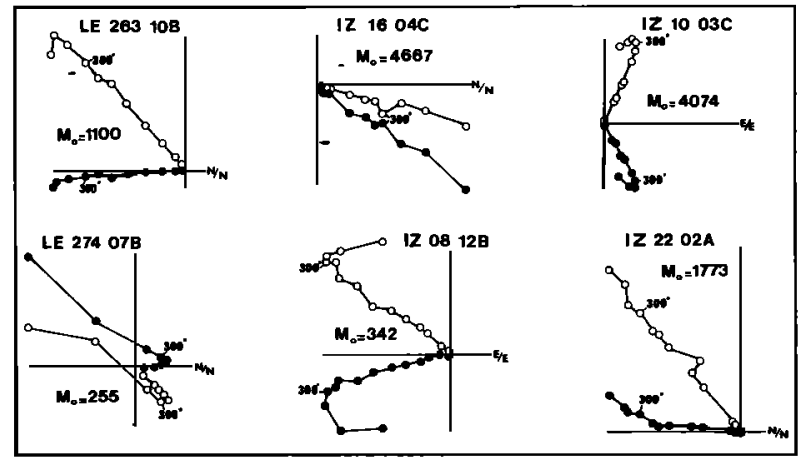

Fig. 2. Typical demagnetization diagrams. Full circles: horizontal projection; open circles: vertical projection. The last step varies between $550^{\circ}$ and $600^{\circ} \mathrm{C}$. Mo (NRM intensity) is reported in $10^{-3} \mathrm{~A} / \mathrm{m}$ unit. regions are on the contrary quite divergent. In Lesbos and in the Canakkale region they are aligned with the N-S direction. The Izmir region is characterized by a $35^{\circ}$ westerly declination,

TABLE I. Paleomagnetic Data From Northeastern Aegea

\begin{tabular}{|c|c|c|c|c|c|c|c|c|}
\hline \multirow{2}{*}{ Sites } & \multirow{2}{*}{$\begin{array}{r}\text { Age } \\
\text { Ma }\end{array}$} & \multirow{2}{*}{$\mathrm{n}$} & \multicolumn{2}{|c|}{ before B.C } & \multicolumn{2}{|c|}{ after B.C } & & \multirow{2}{*}{$\alpha_{0}$} \\
\hline & & & D & I & D & $\mathbf{I}$ & & \\
\hline \multicolumn{9}{|c|}{ Canakkale Region 1} \\
\hline $\begin{array}{l}850 \\
851 \\
Z 52 \\
854\end{array}$ & $\begin{array}{l}---- \\
--- \\
---- \\
---\end{array}$ & $\begin{array}{l}8 \\
8 \\
9\end{array}$ & $\begin{array}{r}194.0 \\
183.2 \\
176.6 \\
8.3\end{array}$ & $\begin{array}{r}-65.0 \\
-70.4 \\
-69.6 \\
60.5\end{array}$ & $\begin{array}{r}194.0 \\
183.2 \\
176.6 \\
8.3\end{array}$ & $\begin{array}{r}-50.0 \\
-55.4 \\
-54.6 \\
45.5\end{array}$ & $\begin{array}{r}24 \\
252 \\
165 \\
205\end{array}$ & 1 \\
\hline
\end{tabular}

\section{Lesbos Island ${ }^{2}$}

\begin{tabular}{|c|c|c|c|c|c|c|c|c|}
\hline LE249 & --- & 10 & 8.0 & 37.0 & 11.2 & 27.0 & 280 & 2.6 \\
\hline 252 & --- & 8 & 0.2 & 49.0 & 4.8 & 40.2 & 153 & 4.0 \\
\hline 253 & --- & 9 & 13.6 & 59.5 & 17.2 & 49.7 & 196 & 4.0 \\
\hline 255 & -- & 11 & -- & -- & 11.3 & 53.3 & 704 & 1.6 \\
\hline 256 & 16.9 & 11 & --- & ---- & 340.5 & 55.0 & 229 & 2.8 \\
\hline 257 & 16.9 & 10 & ---- & ---- & 350.0 & 69.0 & 262 & 3.0 \\
\hline 263 & 18.0 & 9 & 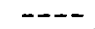 & ---- & 177.8 & -49.0 & 1333 & 1.3 \\
\hline $\mathrm{LE} 269$ & 18.0 & 8 & ---- & ---- & 146.0 & -63.6 & 177 & 3.7 \\
\hline LE2 71 & 18.0 & 11 & --- & --- & 214.0 & -20.0 & 15 & 10.0 \\
\hline & 8.0 & 10 & ---- & --- & 191.7 & -44.7 & 181 & 3.3 \\
\hline 2273 & 15.5 & 10 & 31.4 & 58.5 & 19.1 & .0 & 257 & \\
\hline 274 & 15.5 & 10 & 358.6 & 44.3 & 353.5 & 38.7 & 134 & 3.8 \\
\hline 8275 & 15.5 & 9 & - & & 17.3 & 64.0 & 233 & 3. \\
\hline LE277 & 15.5 & 9 & --- & --- & 349.5 & 45.5 & 170 & 3.5 \\
\hline & & 9 & --- & & 1 & & 72 & 5 \\
\hline LE279 & 18.0 & 7 & --- & ---- & 199.5 & -20.0 & 144 & 4. \\
\hline $\operatorname{LE} 280$ & 18.0 & 7 & --- & ---- & 191.0 & -41.0 & 46 & 7.8 \\
\hline & & & {$[z m i$} & ama & $g]$ & & & \\
\hline 206 & 11.3 & 12 & $-\cdots$ & ---- & 128.0 & -47.0 & 158 & 4.2 \\
\hline 1207 & 11.7 & & 144.0 & -34.0 & 141.0 & -39.5 & 249 & 3. \\
\hline IZ09 & 7.0 & 12 & 169.0 & -62.5 & 127.2 & -41.0 & 93 & 4.2 \\
\hline I 210 & 7.0 & - & 192.0 & -55.0 & 144.0 & -47.5 & 500 & 2.2 \\
\hline I 224 & & 7 & - & $-\cdots$ & 348.0 & 64.0 & 56 & 7.0 \\
\hline I Z28 & & 8 & 346.0 & 54.0 & 349.6 & 57.0 & 57 & 4.0 \\
\hline 1244 & 18.2 & 9 & $\cdots$ & ---- & 342.0 & 71.4 & 828 & 1. \\
\hline IZ46 & 18.2 & 8 & 319.5 & 53.8 & 314.0 & 53.8 & 540 & 2 \\
\hline 12 & & & 328.0 & 36.6 & 325.0 & 14 & 35 & \\
\hline IZ59 & $-\cdots$ & 18 & 36.4 & 54.0 & 336.0 & 58.5 & 27 & 6. \\
\hline 60 & --- & 10 & 50.6 & 58.2 & 331.0 & & 76 & \\
\hline IZ61 & ---- & 9 & - & --- & 333.0 & 31.7 & 47 & 6. \\
\hline I764 & --- & 10 & $\sim-$ & - & 165.2 & -67.2 & 115 & \\
\hline & & & out & OI Be & & & & \\
\hline I 222 & 17.5 & 11 & -.-- & ----- & 190.0 & -48.0 & 387 & 2.4 \\
\hline 247 & 17.5 & 0 & --- & $-\cdots$ & 7.2 & & 45 & 7 \\
\hline 48 & 17.5 & 8 & --- & & 226.5 & -28.8 & 12 & 14.0 \\
\hline & & & Karabu & run $P$ & $\mathbf{n} \varepsilon$ & & & \\
\hline $\mathrm{zo}$ & 18.5 & 11 & $-\cdots$ & $-\cdots$ & 267.0 & -34.5 & 23 & 8. \\
\hline 214 & & 8 & 181.0 & -51.0 & 182.0 & -36.0 & 264 & 3 \\
\hline 1215 & 17. & 5 & & ---2 & 226.0 & -84.5 & 35 & 10.5 \\
\hline 216 & 21.3 & 6 & --- & ---- & 43.5 & 16.3 & 97 & \\
\hline 1245 & 18.5 & 8 & -- & ---- & 234.0 & -53.5 & 450 & 2 \\
\hline Cesme & 18.5 & 7 & --- & ---- & 254.0 & -51.9 & 189 & 4 \\
\hline & 18.5 & 7 & ---- & ----- & 237.0 & -51.5 & 52 & \\
\hline $\operatorname{lma}^{3}$ & & 5 & ---- & & 207.0 & -59.5 & 132 & 6 \\
\hline
\end{tabular}

Mean regional directions after bedding correction:

$$
\begin{array}{llll}
1_{\mathrm{N}}=4 / 6 ; & \mathrm{D}=6 ; & \mathrm{I}=54 ; \mathrm{K}=254 ; & \alpha_{95}=4.3 \\
2_{\mathrm{N}}=17 / 27 ; & \mathrm{D}=6 ; & \mathrm{I}=49 ; \mathrm{K}=25 ; & \alpha_{95}=6.8 \\
3_{\mathrm{N}}=13 / 23 ; & \mathrm{D}=327 ; \mathrm{I}=52 ; \mathrm{K}=20 ; & \alpha_{95}=8.7 \\
4 \mathrm{~N}=3 / 4 ; & \mathrm{D}=22 ; & \mathrm{I}=39 ; \mathrm{K}=16 ; & \alpha_{95}=20.2 \\
5_{\mathrm{N}}=8 / 10 ; & \mathrm{D}=49 ; & \mathrm{I}=51 ; \mathrm{K}=9 ; & \alpha_{95}=16.4
\end{array}
$$

The $K / A r$ ages refer to the sampled units but have not been determined on single sites. 


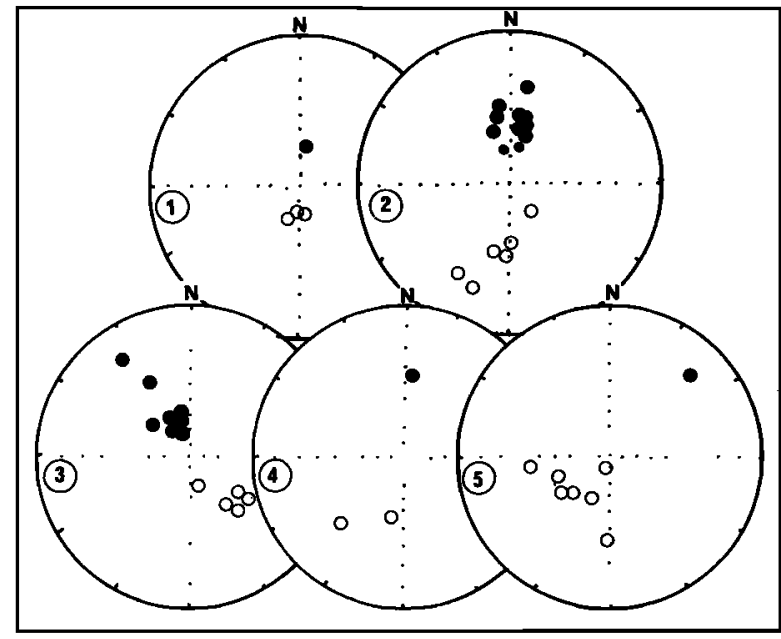

Fig. 3. Stereographic projections of the stable paleomagnetic direction obtained for the reliable sites. Each stereogram corresponds to sites from a particular region. Symbols: 1: Canakkale region; 2: Lesbos island; 3: ImmirBergama region; 4: south of Bergama; 5: Karaburun peninsula.

except for the 3 sites south of Bergama where a $20^{\circ}$ easterly declination is observed. In the Karaburun peninsula the declinations are all deviated eastward (mean value $49^{\circ}$ ) with a large scatter. We have no explanation for this scatter which is not, in our opinion, related to erroneous declination values arising from the use of the usual tilt correction about the strike of the dip. Indeed all the measured dips in this region are of the order of $20^{\circ}-30^{\circ}$, so that very limited effects are to be expected in this case (McDonald, 1980).

\section{Discussion}

A recent examination of all the available paleomagnetic data from the Aegea leads to the conclusion that this entire domain has been linked to the African plate during most of its tertiary geodynamical evolution (Kissel and Laj, 1987). Using the Miocene African poles proposed by Westphal et al. (1986), the expected paleomagnetic direction in the studied region is $D=5.8^{\circ} ; I=53.2^{\circ}$. Thus the observed inclination values are in good agreement with the expected ones. An examination of the observed declinations then indicates quite a complex pattern of rotations of adjacent blocks. Indeed, while Iesbos and the Canakkale region have not undergone any significant rotation, the Karaburun Peninsula has been affected by a $44^{\circ}$ clockwise rotation and the Izmir region has undergone a $37^{\circ}$ anticlockwise rotation. The volcanic massif located south of Bergama has rotated clockwise with an angle of some $18^{\circ}$.

All the results are schematically summarized in Figure 4 which shows the amount of rotation and the inferred limits of the different blocks delineated by the paleomagnetic results. Two blocks, the Canakkale region and the small block south of Bergama, are not defined by a sufficient number of sites. However, if their geographical limits are doubtful, we believe that the differences of their paleomagnetic directions from those of the surrounding regions are real.

The ages of the rotations are constrained by the ages of the volcanic and sedimentary rocks that underwent rotation. Therefore only lower limits may be provided. Whatever the age of the studied rocks, in each region, the measured rotation is coherent indicating that the rotation post-dates the formation of the youngest studied rock. In the Izmir region, the youngest published data is a $\mathrm{K} / \mathrm{Ar}$ age of $11.3 \mathrm{Ma}$ (Borsi et al., 1972). However, we have recently obtained a $\mathrm{K} / \mathrm{Ar}$ age of $7 \mathrm{Ma}$ for a volcanic formation sampled near Foça.

Moreover, most of the neotectonic faults in the region were initiated during the late Miocene-Early Pliocene. The $7 \mathrm{Ma}$ date for the Foça basalts indicates that the rotation of this region, quite coherent at all the sites, definitively belong to the neotectonic activity. The sites studied in the Karaburun peninsula are all situated in formations older than $16 \mathrm{Ma}$, so that the rotation cannot be directly time-bracketed. However, it seems unreasonable to us that the rotation of the Karaburun Peninsula has occurred during the pre-11 $\mathrm{Ma}$ activity and is thus not related to the other rotations of this area. The other sites exhibiting coherent rotations are all in rocks younger than $16 \mathrm{~m} . \mathrm{y} .$.

\section{Conclusions}

The paleomagnetic data we have collected, between the North-Anatolian and the Alasehir faults demonstrate significant clockwise and counterclockwise rotations of coherent blocks that took place during the neotectonic extensional regime. Such rotations are difficult to explain in the framework of the global geodynamical evolution of the Western Anatolian and Eastern Aegean regions and are most probably related to a local tectonic regime. In our opinion, these results show that the brittle upper part of the lithosphere does not

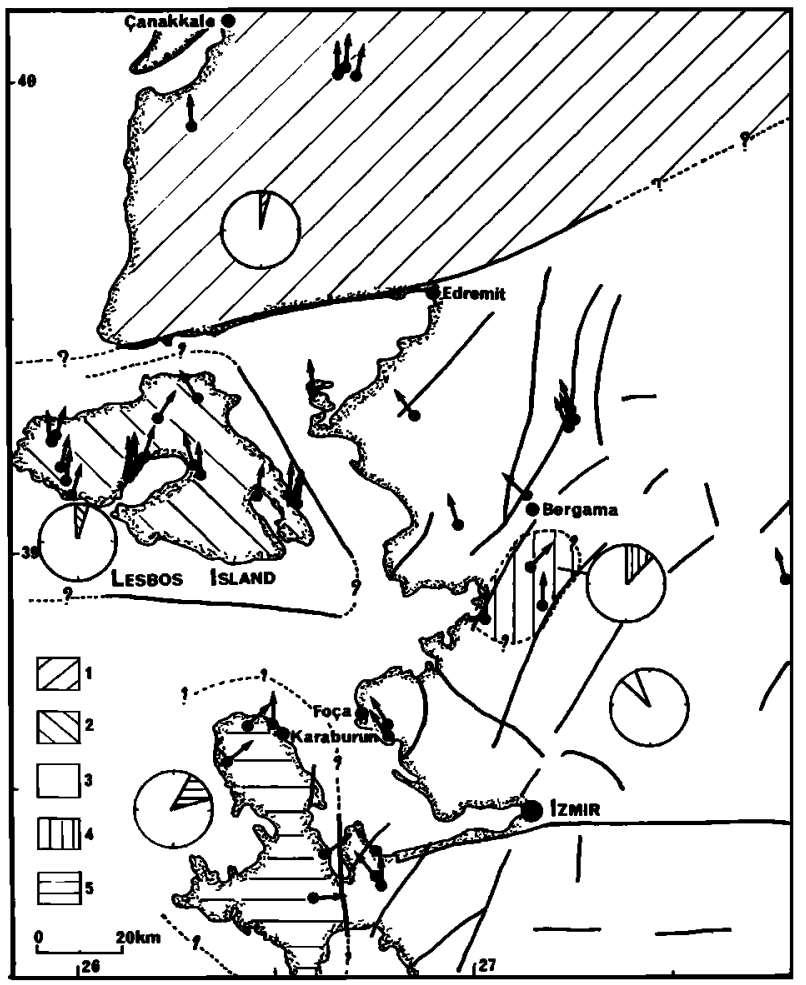

Fig. 4. Mean values of the declinations in the studied area.The reverse directions have been inverted through the origin. For the different regions (same numbers than in Fig.3), the amount and the sense of the rotation are shown on a stereogram. The limits of the different rotating units are only intended as a visual support to identify zones of coherent rotation. 
everywhere passively follow the motions of its lower ductile part or that the latter motions are more complex than hitherto assumed.

We think that the main characteristics of the observed rotational pattern can be explained by a recently proposed model for rotations in extensional zones in which there is no commensurate strike-slip faulting (Sengör et al., 1985, Fig. 18). An important feature of this model is the implication that large $\left(>20^{\circ}\right)$ rotations arise from successive episodes of faulting, older faults being cut and rotated passively by younger ones. This feature explains the complex pattern of faulting seen in these regions.

A more detailed analysis of the structural and the paleomagnetic data is now under way to develop a better constrained geometrical model, as it has already been done in purely

strike-slip context of deformation (Garfunkel et al., 1974; Ron et al., 1984; Brown and Golombek, 1986; Hornafius et al., 1986).

Aknowledgments. We wish to thank P.Y. Gillot who took care of the K/Ar age determination. The financial support was given by the CEA, the CNRS and the INSU ATP: Blocs et Collisions.

CER Contribution 857 .

\section{References}

Angelier, J., J. F. Dumont, H. Karamanderesi, A. Poisson, S. Simsek, and S. Uysal, Analyses of fault mechanisms and expansion of Southwestern Anatolia since the Late Miocene, Tectonophysics, 75, T1-T9, 1981.

Borsi, S., G. Ferrara, F. Innocenti, and R. Mazzuoli, Geochronology and Petrology of recent volcanics in the Eastern Aegean Sea (Western Anatolia and Lesbos island), Bull. volc, XXXVI-3, 473-496, 1972

Brown, L.L. and M. P. Golombek, Tectonic rotations within the Rio Grande rift: evidence from paleomagnetic studies, J. Geophys. Res. 20, 790-802, 1985.

Dewey, J. F., and A. M. C. Sengör, Aegean and surrounding regions: complex multiplate and continuum tectonics in a convergent zone, Geol. Soc. America Bull, 90 (I), 84-92, 1979.

Eyidoğan, H., and J. Jackson, A seismological study in the Dermici, Alasehir and Gediz earthquakes of 1969-70 in Western Turkey: implications for the nature and geometry of deformation in the continental crust. Geophys. J. R. Astron. Soc., 81, 569-607, 1985.

Fytikas, M., F. Innocenti, P. Manetti, R. Mazzuoli, A. Peccerillo, and L. Villari, Tertiary to Quaternary evolution of volcanism in the Aegean region, Soc. Geol. London, Spec. Publ. $0^{\circ} 17,687-700,1984$.

Garfunkel, - Z. V. I., Model for the Late Cenozoic tectonic history of the Mojave desert, California, and for its relation to adjacent regions, Geol. Soc. Am. Bull, 85, 1931-1944, 1974 .
Hornafius, J. S., B. P. Luyendyk, R. R. Terres, and $M$. J. Kamerling, Timing and extent of Neogene tectonic rotation in the western Transverse Ranges, California. Geol. Soc. Am. Bul1, 97, 1476-1487, 1986.

Kaya, 0., Miocene reference section for the coastal parts of West Anatolia, Newsl. Stratigr, 10, 164-191, 1981.

Kissel, C. and C. Laj, The Tertiary geodynamical evolution of the Aegean arc: a paleomagnetic reconstruction, Tectonophysics, in press, 1987.

Lauer, J.P., L'évolution géodynamique de la Turquie et de Chypre déduite de l'etude paléomagnétique, Thèse Univ., 299pp., Louis Pasteur, Strasbourg, 1981

Le Pichon, X. and J. Angelier, The Aegean Sea, Phil. Trans. Roy. Soc. Iondon, A300, 357-372, 1981 .

McDonald, W.D., Net tectonic rotation, apparent tectonic rotation and the structural tilt correction in paleomagnetic studies, $\mathbf{I}$. Geophys. Res, 85, 3659-3669, 1980

McKenzie, D. P., Active tectonics of the AlpineHimalayan belt: the Aegean Sea and surrounding regions, Geophys. J. R. Astron. Soc. 55, 217-254, 1978 .

Mercier, J.L., M. Delibassis, A. Gauthier, J. J . Jarrige, E. Lemeille, H. Philip, M. Sébrier, and D. Sorel, La neotectonique de I'Arc Egéen, Rey. Geol. Dyn. Geogr. Phys., 21, $61-72,1979$.

Ron, H., R. Freund, Z. Garfunkel, A. Nur, Block rotation by strike-slip faulting: structural and paleomagnetic evidence, J.Geophys. Res., 89, B7, 6256-6270, 1984 .

Sengör, A. M. C., N. Görür and F. Saroglu, Strike-slip faulting and related basin formation in zones of tectonic escape: Turkey as a case study, Soc. Econ. Paleont. Min. Spec. Pub., 37, 227-264, 1985.

Tapponnier,P., Evolution tectonique du système alpin en Mediterranée: poinçonnement et écrasement rigido-plastique, Bull. Soc. Geol. Er., 19, 437-460, 1977.

Westphal,M., M.L. Bazhenov, J. P. Lauer, D. M. Pechersky and J. C. Sibuet, Paleomagnetic implications on the evolution of the Tethys belt from the Atlantic ocean to Pamir since Trias, Tectonophysics, 123, 37-82, 1986.

C. Kissel and C. Laj, Centre des Faibles Radioactivites, Laboratoire mixte CEA/CNRS Domaine du CNRS, BP1, 91190 Gif-sur-Yvette, France.

A.M.C. Sengör, ITU Maden Fakultesi, Jeoloji Mühendisligi Bölümü, Tesvikiye, Istanbul, Turkey.

A. Poisson, Laboratoire de Geologie Historique, Université Paris XI, 91405 Orsay Cedex, France.

(Received May 8, 1987 revised July 14; 1987; accepted July $14 ; 1987$ ) 